Article

\title{
Evaluation of Compost and Biochar to Mitigate Chlorpyrifos Pollution in Soil and Their Effect on Soil Enzyme Dynamics
}

\author{
Humera Aziz ${ }^{1, *}$, Xiukang Wang ${ }^{2, * \mathbb{D}}$, Ghulam Murtaza ${ }^{3, * \mathbb{D}}$, Ambreen Ashar ${ }^{4} \mathbb{D}$, Sarfraz Hussain ${ }^{5}$, \\ Muhammad Abid ${ }^{6}$ (D), Behzad Murtaza ${ }^{7}$, Muhammad Hamzah Saleem ${ }^{8}$, Sajid Fiaz ${ }^{9}$ and Shafaqat Ali ${ }^{1,10, *(\mathbb{D})}$
}

check for updates

Citation: Aziz, H.; Wang, X.; Murtaza, G.; Ashar, A.; Hussain, S.; Abid, M.; Murtaza, B.; Saleem, M.H.; Fiaz, S.; Ali, S. Evaluation of Compost and Biochar to Mitigate Chlorpyrifos Pollution in Soil and Their Effect on Soil Enzyme Dynamics. Sustainability 2021, 13, 9695. https://doi.org/ $10.3390 /$ su13179695

Academic Editors: Vinod Kumar and Raj Setia

Received: 6 June 2021

Accepted: 25 August 2021

Published: 29 August 2021

Publisher's Note: MDPI stays neutral with regard to jurisdictional claims in published maps and institutional affiliations.

Copyright: (c) 2021 by the authors. Licensee MDPI, Basel, Switzerland. This article is an open access article distributed under the terms and conditions of the Creative Commons Attribution (CC BY) license (https:/ / creativecommons.org/licenses/by/ $4.0 /)$.
1 Department of Environmental Sciences and Engineering, Government College University, Faisalabad 38040, Pakistan

2 College of Life Sciences, Yan'an University, Yan'an 716000, China

3 Institute of Soil and Environmental Sciences, University of Agriculture, Faisalabad 38000, Pakistan

4 Department of Chemistry, Government College Women University, Faisalabad 38860, Pakistan; ambreenashar2013@gmail.com

5 Pesticide Quality Control Laboratory, Ayub Agricultural Research Institute, Faisalabad 38850, Pakistan; acpesticides@gmail.com

6 Department of Statistics, Government College University, Faisalabad 38000, Pakistan; mabid@gcuf.edu.pk

7 Department of Environmental Sciences, Vehari-Campus, COMSATS University Islamabad, Vehari 61100, Pakistan; behzadmurtaza@cuivehari.edu.pk

8 College of Plant Science and Technology, Huazhong Agricultural University, Wuhan 430070, China; saleemhamza312@webmail.hzau.edu.cn

9 Department of Plant Breeding and Genetics, The University of Haripur, Haripur 22620, Pakistan; sfiaz@uoh.edu.pk

10 Department of Biological Sciences and Technology, China Medical University, Taichung 40402, Taiwan

* Correspondence: humeraaziz.uaf@gmail.com (H.A.); wangxiukang@yau.edu.cn (X.W.); gmurtazauaf@gmail.com (G.M.); shafaqataligill@yahoo.com (S.A.)

Abstract: The widespread environmental contamination of chlorpyrifos (CP) has raised human health concerns and necessitated cost-effective methods for its remediation. The current study evaluated the degradation behavior of CP in compost and biochar amended and unamended (original and sterilized) soils in an incubation trial. Two levels of CP (100 and $\left.200 \mathrm{mg} \mathrm{kg}^{-1}\right)$, compost and biochar $(0.50 \%)$ were applied, and soil was collected at different time intervals. At the higher CP level $\left(200 \mathrm{mg} \mathrm{kg}^{-1}\right), \mathrm{CP}$ a showed lower degradation rate $\left(\mathrm{K}=0.0102 \mathrm{mg} \mathrm{kg}^{-1} \mathrm{~d}^{-1}\right)$ compared with a low $\mathrm{CP}$ level $\left(\mathrm{k}=0.0173 \mathrm{mg} \mathrm{kg} \mathrm{k}^{-1} \mathrm{~d}^{-1}\right)$. The half-lives of $\mathrm{CP}$ were 40 and 68 days for $\mathrm{CP}$ at 100 and $200 \mathrm{mg} \mathrm{kg}^{-1}$ in original soil, respectively, and increased to 94 and 141 days in sterilized soils. $\mathrm{CP}$ degradation was accelerated in compost amended soils, while suppressed in biochar amended soils. Lower half lives of 20 and 37 days were observed with compost application at CP 100 and $200 \mathrm{mg} \mathrm{kg}^{-1}$ doses, respectively. The activities of soil enzymes were considerably affected by the CP contamination and significantly recovered in compost and biochar amended soils. In conclusion, the application of organic amendments especially compost is an important strategy for the remediation of CP contaminated soil.

Keywords: biochar; chlorpyrifos; compost; pollution; remediation; soil enzymes activities

\section{Introduction}

The common practice of applying synthetic pesticides on a large scale to improve agricultural production has resulted in a severe soil contamination [1]. Many pesticides currently in use have shown negative impacts on plant growth, soil fertility and soil microbial population functioning and diversity, causing potential long-term damage to the sustainability of agricultural systems [2,3]. Moreover, the degradation products of some pesticides exhibit higher mobility than their parent compounds and contaminate groundwater by soil infiltration and surface water by sediments runoff [4-6]. CP is extensively 
used to kill soil insect pests in the agricultural sector [7]. However, $\mathrm{CP}$ is relatively persistent in the environment, with a half-life in soil from 60-120 days [8] and is also highly toxic to both terrestrial and aquatic organisms [9] by causing immunotoxic and neurotoxic effects in humans and animals $[10,11]$. The presence of chlorpyrifos can be detected in agricultural soil and water samples throughout the world, even after it has been banned in most countries [12]. Due to its easy availability, low price and expensive agricultural basis, chlorpyrifos is the most commonly used pesticide in South America and Asian countries such as Pakistan, India, etc. $[13,14]$. Consequently, the extensive use of $\mathrm{CP}$, coupled with the detection of $\mathrm{CP}$ and its residues in agricultural products, foodstuffs, surface and ground water bodies, soil and human blood samples, has attracted much scientific interest as a human and environmental health concern which requires urgent action to assess and treat the problem [13-15].

Compost is a material formed after the partial decomposition of organic waste in aerobic conditions, and it has a potential for the abatement of pollution from soil [16] and is used as a soil conditioner. Biochar is a product formed after the pyrolysis of solid organic material in anoxic conditions [17]. Both amendments are pretty good options for reducing the volume of organic wastes and have their implications for tackling soil pollution [18]. The supplementation of soil with biochar and compost is known to increase the fertility and physicochemical properties of soils such as soil water holding capacity, $\mathrm{pH}$, organic matter contents, cation exchange capacity (CEC), etc. [19]. Such amendments can also affect the fate of soil pesticides by providing multiple additional sorbent surfaces, which reduces their leaching potential [20-22] and can enhance their degradation [23]. Since the activity of soil enzymes is a good measure of soil quality, the soil metabolic rate can be used to demonstrate the effectiveness of any remedial processes adopted to treat pesticide-contaminated soils [24,25]. The widespread use of synthetic pesticide has increased the environmental and human health concerns, where cost-effective strategies to immobilize pesticides residues or accelerate their degradation in soil is necessary to ensure food safety $[26,27]$. Most of the soil enzymes are excreted by the soil microbes, while only a few are produced by flora and fauna in the soil [28]. The soil enzymes quickly respond to the environmental stresses that affect the soil [29]. Previous studies have reported the effect of pesticides' toxicity on soil enzymes activities. The positive effect of biochar has been reported in previous studies by recovering soil enzyme activities under pesticide pollution [30]; however, the studies regarding the effect of compost on soil enzyme activities in CP contaminated soil are very rare. Moreover, the comparative behavior of biochar and compost on the degradation of chlorpyrifos and on the soil enzymes activities under $\mathrm{CP}$ toxicity in Pakistani soil conditions is lacking in the literature. Therefore, the current research was carried out to (1) investigate the degradation of $\mathrm{CP}$ in biochar and compost supplemented and non-supplemented sterilized and original (non-sterilized) soils and (2) to evaluate the influence of biochar and compost amendments on soil enzymes activities in a CP contaminated soil.

\section{Materials and Methods}

\subsection{Pesticide and Chemicals}

Technical grade (97\%) CP was obtained from Ali Akbar Enterprises, Pvt. Ltd. Lahore, Pakistan. Analytical grade (99.5\%) CP was purchased from Dr. Ehrenstorfer GmbH (Germany). Analytical grade n-hexane and acetone were purchased from Merck (Darmstadt, Germany).

\subsection{Soil and Amendments Preparation, Contamination and Incubation}

An incubation trial was performed in the growth room at the Institute of Soil and Environmental Sciences, University of Agriculture Faisalabad, Pakistan, to test the degradation behavior of CP in unamended (sterilized and non-sterilized) and amended (sterilized and non-sterilized) soils with biochar and compost. The soil (sandy clay loam) was collected from the upper $(0-30 \mathrm{~cm})$ farm area of Village No.132/GB in Faisalabad, Pakistan. The 
soil was air dried in the shade for one week, and thereafter sieved using a $2 \mathrm{~mm}$ sieve and mixed thoroughly. Biochar was produced at a pyrolysis temperature of $500{ }^{\circ} \mathrm{C}$ using wheat straw as a feedstock under limited oxygen conditions in a laboratory muffle furnace as previously stated [31]. Compost was produced from agricultural waste material and plant leaves as described previously [32]. After homogenization and drying at room temperature for 7 days, both amendments were finely grounded and sieved $<200 \mu \mathrm{m}$. The physicochemical characteristics of the biochar, compost and soil are given in Supplementary Data Table S1. The two amendments (biochar and compost) were thoroughly mixed with the soil by hand to achieve loading $0.50 \%(w / w)$ for biochar and compost, respectively. Soil was taken in glass jars (200 g each). Before the experiment, the soil in the jars was pre-incubated for a week at $25^{\circ} \mathrm{C}$ at $40 \%$ of water holding capacity (WHC). The soil was spiked with a CP solution (prepared in acetone) to give two spiked concentrations of 100 and $200 \mathrm{mg} \mathrm{CP} \mathrm{kg}^{-1}$ soil. The full treatments descriptions and their abbreviations are elaborated in Supplementary Data Table S2. The capped jars were shaken on a rotary shaker for $24 \mathrm{~h}$ in order to facilitate complete mixing of soil and pesticide solution and were subsequently placed unsealed in fume hood for two days to allow for the evaporation of acetone. Another set of jars were prepared identically in three replicates with the same treatment combinations as above, except sterilized soils were used in each treatment. Soil was sterilized twice (prior to spiking with CP solution) in an autoclave at $120^{\circ} \mathrm{C}$ for $30 \mathrm{~min}$ under $300 \mathrm{kPa}$ pressure chamber [33]. The jars were incubated in the dark at $20 \pm 5{ }^{\circ} \mathrm{C}$ for four months, where soil moisture was maintained (at 40\% WHC) by adding distilled water. The sterile distilled water was used for sterile soil treatments. In order to avoid disturbance and to ensure accuracy, separate set of jars were prepared for each sampling date. Soil samples (20 g) were periodically taken from each jar at $0,7,15,30,60$ and 120 days. The collected soil samples were divided into two subsamples for pesticide and enzymatic analysis. The samples for pesticide residual concentration were stored at $-20{ }^{\circ} \mathrm{C}$ so that the pesticide recovery may not be affected while. For the soil enzymatic analysis, the samples were kept at $4{ }^{\circ} \mathrm{C}$, and enzymatic analyses were completed within $48 \mathrm{~h}$ of sample collection for each respective interval.

\subsection{Chemical Analysis}

The EC and $\mathrm{pH}$ of biochar, compost, and soil were determined on suspensions of solid: distilled water (1:20[w/v] and 1:10 [w/v], respectively [34]) using conductivity (HANNA HI8033) and pH meters (JENCO Model-671P). Soil texture was determined using the method described by [35]. The specific surface area of all samples and pore characteristics of biochar and compost were determined from $\mathrm{N}_{2}$ adsorption isotherms at $77 \mathrm{~K}$ using surface area analyzer (Beckman Coulter SA3100, Brea, CA, USA). Before filling with $\mathrm{N}_{2}$ gas at different pressures, the degassing of the samples was done for $1 \mathrm{~h}$ at $363 \mathrm{~K}$ and then again for $3 \mathrm{~h}$ at $623 \mathrm{~K}$. The $\mathrm{N}_{2}$ adsorption data was plotted versus relative vapor pressure and computation of BET specific surface area was done by computer using BET equation. The pore size and pore volume were computed using NOVA Win 2.0 software with $\mathrm{N} 2$ adsorption data [36]. The CEC was determined by modified $\mathrm{NH}_{4}{ }^{+}$ acetate method. First the samples $(0.2 \mathrm{~g})$ were leached with deionized water, and the sum of basic cations in the leachate were determined. Afterwards, $20 \mathrm{~mL}$ of $1 \mathrm{M} \mathrm{Na}^{+}$acetate ( $\mathrm{pH} 7$ ) was added in the samples to determine $\mathrm{Mg}^{2+}, \mathrm{Ca}^{2+}$ and $\mathrm{K}^{+}$as exchangeable base cations in the leachate. Then, the exchangeable $\mathrm{Na}^{+}$was removed by washing with ethanol $(20 \mathrm{~mL})$. After this, $20 \mathrm{~mL}$ of $\mathrm{NH}_{4}{ }^{+}$-acetate $\left(\mathrm{pH}\right.$ 7) was added in order to displace $\mathrm{Na}^{+}$on the exchangeable sites. Afterwards the CEC was calculated by using a flame photometer as described by [37]. The total organic carbon in soil samples was determined by oxidation for $30 \mathrm{~min}$ at $150-160{ }^{\circ} \mathrm{C}$ with $\mathrm{K}_{2} \mathrm{Cr}_{2} \mathrm{O}_{7}$ and then excessive dichromate was titrated with ferrous ammonium sulphate [38], and the total organic carbon contents in compost and biochar samples were determined on TRL-TOC/TN analyzer made in Anarkara, Turkey. 


\subsubsection{Soil Extraction of Chlorpyrifos}

Soil $(1 \mathrm{~g})$ was weighed directly into glass centrifuge tubes $(50 \mathrm{~mL})$. A mixture of acetone and $\mathrm{n}$-hexane $(1: 1(v / v) ; 10 \mathrm{~mL})$ was added and the mixture rigorously agitated on a vortex mixture for $1 \mathrm{~min}$. Subsequently, the mixture was subjected to ultrasonic extraction on an ultrasonic bath Bandelin RK 100H, 80/160 W (Sonorex, Darmstadt, Germany) $2 \mathrm{~h}$ prior to shaking on an orbital shaker for an additional $12 \mathrm{~h}$. After shaking, the tubes were centrifuged for $15 \mathrm{~min}$ at $1300 \times g$ to separate the solid and liquid phases and the supernatant was removed by pipetting and transferred to glass amber vials after filtration through Whatman glass microfiber filters ( $0.7 \mu \mathrm{m}$ diameter). The filtrate was then dried under $\mathrm{N}_{2}$ gas produced from an air nitrogen generator and the residues re-dissolved in n-hexane (1 mL) for CP determination on a Shimadzu QP-2010 GC-MS [39]. A preliminary recovery experiment carried out with $\mathrm{CP}$ spiked soil samples ranging in concentration from 1 to $10 \mathrm{mg} \mathrm{kg}^{-1}$ gave recoveries ranging from 90 to $92 \%$, thus indicating that the extraction method was reliably recovering total $\mathrm{CP}$ concentrations from soils. The residual CP concentrations in soil samples were determined by GC-MS. The instrument was standardized with standard CP solution prepared using chemical obtained from Sigma-Aldrich. The conditions used were as follows: Injection temperature used was $220^{\circ} \mathrm{C}$, splitless injection mode with a $1 \mathrm{~min}$ sampling time, the oven temperature was kept at $50^{\circ} \mathrm{C}$, the carrier gas used was helium $\left(99.9 \%\right.$ ) at a flow rate of $1.70 \mathrm{~mL} \mathrm{~min}^{-1}$, the solvent cut time was $5 \mathrm{~min}$ and the mode of $\mathrm{CP}$ detection was selected as ion mode. Total program time was $37.17 \mathrm{~min}$, and the monitored mass fragments for $\mathrm{CP}$ were 197, 199, and $314 \mathrm{~m} / \mathrm{z}$.

\subsubsection{Soil Enzymatic Activities}

The activities of three soil enzymes (dehydrogenase, urease and phosphatase) were measured periodically at $0,15,30,60$ and 120 days of incubation. The method of [40] was used to assess soil dehydrogenase activity after incubating soil, where Tris- $\mathrm{HCl}$ buffer of $\mathrm{pH} 7.4$ was used to prepare $5 \mathrm{M}$ TTC solution. Fresh soil samples $(5 \mathrm{~g})$ were incubated in TTC solution $(5 \mathrm{~mL})$ at $37^{\circ} \mathrm{C}$ for $12 \mathrm{~h}$, where, to end the reaction, immediately after incubation, 2 drops of concentrated sulfuric acid were added. Briefly, the TPF extraction procedure was as follows: Soil samples were blended with $5 \mathrm{~mL}$ of toluene $(5 \mathrm{~mL})$ followed by shaking at $250 \mathrm{rpm}$ for $30 \mathrm{~min}$. The centrifugation of samples then done at $4500 \mathrm{rpm}$ for $5 \mathrm{~min}$. After centrifugation, the supernatant solution was decanted carefully avoiding any particulate matter, and the optical density was determined using UV-visible spectrophotometer (Shimadzu, Kyoto, Japan) at $492 \mathrm{~nm}$. The enzyme activity was then reported as $\mu \mathrm{g}$ TPF $\mathrm{g}^{-1}$ soil $12 \mathrm{~h}^{-1}$.

The soil urease activity was assayed as reported by [41] Kandeler and Gerber (1988) utilizing urea as a substrate. Soil $(5 \mathrm{~g})$ was incubated with $2.5 \mathrm{~mL}$ of aqueous urea solution $(0.72 \mathrm{M})$ and $20 \mathrm{~mL}$ of borate buffer $(0.1 \mathrm{M})$ having $\mathrm{pH} 10$ at $37^{\circ} \mathrm{C}$ for $2 \mathrm{~h}$. After incubation, the mixture was extracted with $30 \mathrm{~mL}$ of both $\mathrm{HCl}(0.01 \mathrm{M})$ and $\mathrm{KCl}(1 \mathrm{M})$. The amount of ammonium released in the extract was determined on spectrophotometer (at $690 \mathrm{~nm}$ ) and used to quantify urease activity.

Phosphatase activity was measured with p-nitrophenyl phosphate (PNPP, $0.115 \mathrm{M}$ ) as substrate [42]. This assay is based on the detection of p-nitrophenol (PNP) after releasing. Briefly, air dried soil $(1 \mathrm{~g})$ was incubated for $60 \mathrm{~min}$ at $37^{\circ} \mathrm{C}$ followed by the addition of $1 \mathrm{~mL}$ substrate $(0.5 \mathrm{~mL}), 4 \mathrm{~mL}$ modified universal buffer $(0.1 \mathrm{M})$ of $\mathrm{pH} 6.5$ and $0.25 \mathrm{~mL}$ toluene. To the mixture, $4 \mathrm{~mL}$ of $\mathrm{NaOH}(0.5 \mathrm{M})$ and $1 \mathrm{~mL} \mathrm{CaCl} 2(0.5 \mathrm{M})$ was then added. The mixture was then centrifuged at $2000 \times g$ for $5 \mathrm{~min}$, filtered with Whatman filter (No. 42) and the amount of PNP was determined at $420 \mathrm{~nm}$ spectrophotometrically.

\subsection{Degradation Analysis}

The experimental degradation data was fit to a first order decay model to calculate the degradation rate constant using the equation $C_{t}=C_{0} \times e^{-k t}$, where $C_{t}$ was the concentration of $\mathrm{CP}$ after time $\mathrm{t}\left(\mathrm{mg} \mathrm{kg}^{-1}\right), \mathrm{C}_{0}$ was the initial concentration of $\mathrm{CP}$ at time $0\left(\mathrm{mg} \mathrm{kg}^{-1}\right)$, $\mathrm{k}$ was the degradation rate constant $\left(\mathrm{day}^{-1}\right)$ and $\mathrm{t}$ was the time (days). The half-life of $\mathrm{CP}$ 
was calculated using $t_{1 / 2}=\ln 2 / k$, where $t_{1 / 2}$ was the half-life of $C P$ (days). All data sets were analyzed statistically using Analysis of Variance (ANOVA), and the standard errors (SE) or the standard error of difference between replicates (SED) were reported.

\subsection{Quality Assurance}

All chemicals used in this study were National Institute of Standards and Technology (NIST) traceable and chromatographically pure. The centrifuge tubes and other laboratory consumables were flushed thoroughly with ultrapure water after dipping in $20 \%$ nitric acid solution overnight. A recovery experiment was carried out in order to assure the reliability and quality of the extraction process by spiking the soil with known concentrations of $\mathrm{CP}$ ranging from 1 to $10 \mathrm{mg} \mathrm{kg}^{-1}$, and extraction was done in the same way as described earlier. We obtained recovery values between 90 and 92\%, which showed the good efficiency of the extraction process. For quality control, blank samples were run, which contained only soil. The CP standards (99.5\%) were run for the quantification of CP and then calibration curves were constructed. The linear plots were obtained with $r^{2}>0.96$. Experiments were carried out in three replicates, and the average of these three replications with standard error was reported in results.

\subsection{Statistical Analysis}

The data were tested for normal distribution and homogeneity of variance. Significant differences in CP degradation and enzymes activity were examined using two-way ANOVA (Statistix 8.1 program) following least significant difference (LSD) test at 5\% probability and the main and interaction effects (between treatments and time intervals) were computed. The data computation/graphs were done on Microsoft Excel 2013 ${ }^{\circledR}$ (Microsoft Corporation, Redmond, WA, USA).

\section{Results}

\subsection{Degradation of Chlorpyrifos in Sterile and Non-Sterile Soils}

The concentrations of CP at the initial doses of $100 \mathrm{mg} \mathrm{kg}^{-1}\left(\mathrm{CP}_{100}\right)$ and $200 \mathrm{mg} \mathrm{kg}^{-1}$ $\left(\mathrm{CP}_{200}\right)$ in unamended sterile (SS) and non-sterile soil (NSS) decreased with the increasing incubation time (Figure 1). The degradation of CP followed first order kinetics. The degradation of CP was greater in the NSS over all sampling periods during incubation compared to SS (Figure 1). Under non-sterile conditions, on day 120 (when the incubation experiment ceased), 87 and $71 \%$ of the $\mathrm{CP}_{100}$ and $\mathrm{CP}_{200}$ doses were degraded, respectively, compared to 59 and $49 \%$ under sterile conditions. Clearly microbial activity in the soil increased CP degradation. The half-lives and degradation rates $\mathrm{k}\left(\mathrm{mg} \mathrm{kg}^{-1} \mathrm{~d}^{-1}\right)$ of CP with different treatments are presented in Table 1 . At $\mathrm{CP}_{200}$, the $\mathrm{CP}$ was more resistant towards degradation compared to $\mathrm{CP}_{100}$, with half-lives of 40 and 68 days, respectively, and degradation rates $(\mathrm{k})$ of 0.017 and $0.010 \mathrm{mg} \mathrm{kg}^{-1} \mathrm{~d}^{-1}$ at $C \mathrm{P}_{100}$ and $\mathrm{CP}_{200}$, respectively.

Table 1. Kinetics of degradation of chlorpyrifos in amended and unamended soil.

\begin{tabular}{|c|c|c|c|c|}
\hline \multirow{2}{*}{ Treatment } & \multicolumn{2}{|c|}{ Non-Sterilized Soil } & \multicolumn{2}{|c|}{ Sterilized Soil } \\
\hline & $\mathrm{k}\left(\mathrm{mg} \mathrm{kg} \mathrm{kd}^{-1} \mathrm{~d}^{-1}\right)$ & $t_{1 / 2}(d)$ & $\mathrm{k}\left(\mathrm{mg} \mathrm{kg} \mathrm{kd}^{-1} \mathrm{~d}^{-1}\right)$ & $t_{1 / 2}(d)$ \\
\hline $\mathrm{CP}_{100}$ & $\mathrm{~b} 0.0173$ & ${ }^{c} 40 \pm 5.69$ & a 0.0073 & e $94 \pm 9.00$ \\
\hline $\mathrm{CP}_{100}+\mathrm{FC}$ & a 0.0341 & d $20 \pm 2.00$ & bc 0.0041 & $\mathrm{~d} 169 \pm 17.95$ \\
\hline $\mathrm{CP}_{100}+\mathrm{WSB}$ & c 0.0122 & b $57 \pm 7.00$ & d 0.0022 & b $318 \pm 31.18$ \\
\hline $\mathrm{CP}_{200}$ & cd 0.0102 & e $68 \pm 8.00$ & ${ }^{b} 0.0049$ & d $141 \pm 20.82$ \\
\hline $\mathrm{CP}_{200}+\mathrm{FC}$ & b 0.0189 & c $37 \pm 5.29$ & cd 0.0031 & ${ }^{c} 220 \pm 26.46$ \\
\hline $\mathrm{CP}_{200}+\mathrm{WSB}$ & d 0.0075 & a $93 \pm 9.61$ & $\mathrm{~d} 0.0016$ & a $426 \pm 37.29$ \\
\hline
\end{tabular}

$\overline{\mathrm{k}}=$ degradation rate for $\mathrm{CP}, \mathrm{t}_{1 / 2}=$ Half-life. Values are presented as means of three replicates for degradation rate and half-lives \pm standard deviation. The different letters in same columns represent significant different between treatments. 


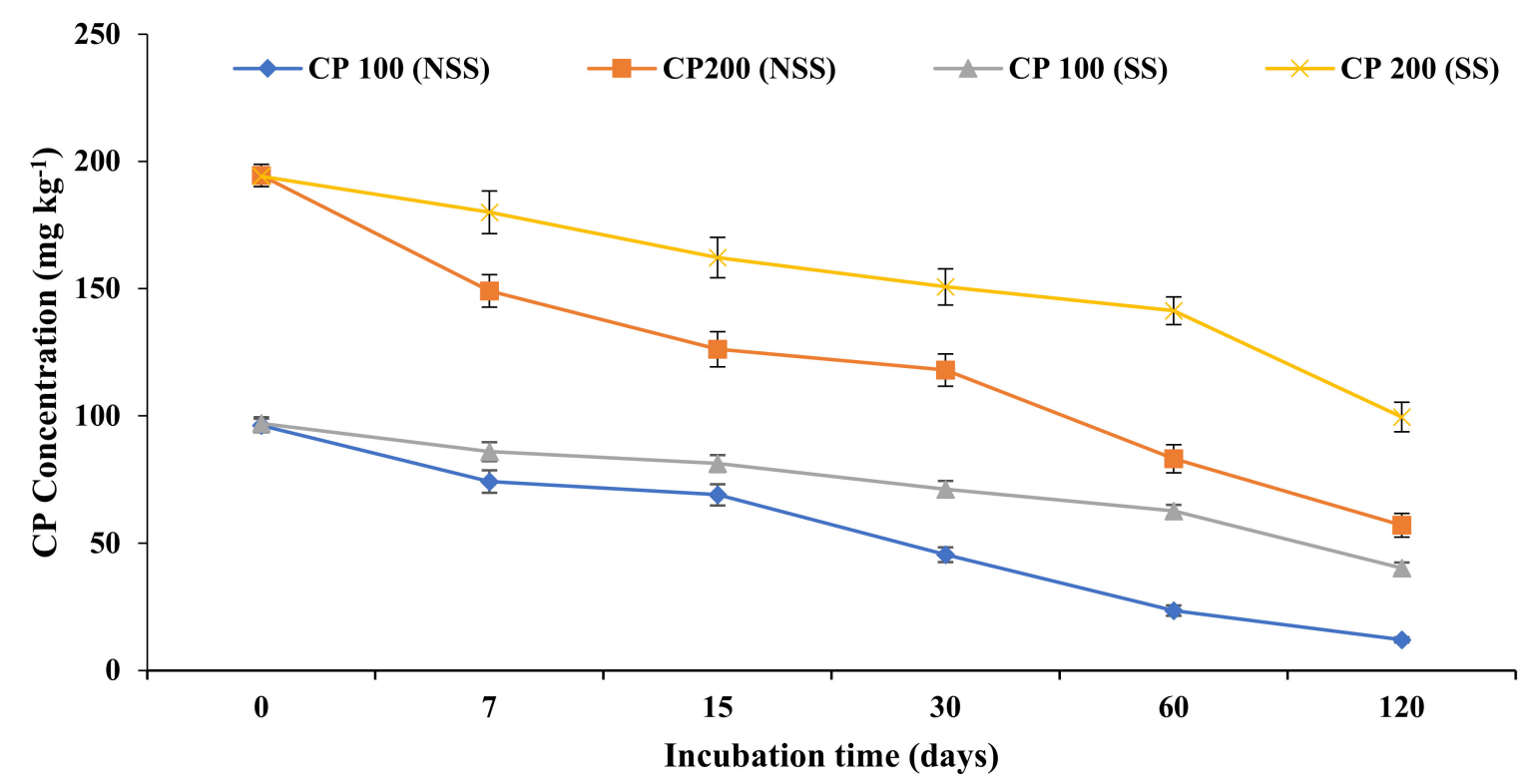

Figure 1. Degradation of chlorpyrifos (CP) in non-sterilized and sterilized soils at two different initial CP concentrations (100 and $200 \mathrm{mg} \mathrm{kg}^{-1}$ ); CP100(NSS) = CP $100 \mathrm{mg} \mathrm{kg}^{-1}$ with non-sterilized soil, CP200(NSS) = CP $200 \mathrm{mg} \mathrm{kg}^{-1}$ with non-sterilized soil, CP100(SS) $=$ CP $100 \mathrm{mg} \mathrm{kg}^{-1}$ with sterilized soil, CP200(SS) $=$ CP $200 \mathrm{mg} \mathrm{kg}^{-1}$ with sterilized soil.

\subsection{Influence of Compost and Biochar Amendments on Chlorpyrifos Degradation}

The effect of the compost and biochar application on the degradation of $\mathrm{CP}$ at the initial doses of $100\left(\mathrm{CP}_{100}\right)$ and $200\left(\mathrm{CP}_{200}\right) \mathrm{mg} \mathrm{kg}^{-1}$ in NSS is illustrated in Figure 2. The main and interaction effects between treatments and time intervals is presented in Supplementary Data Table S3. In the NSS, the compost and biochar amendments had different effects on the degradation of $\mathrm{CP}$ at both doses of $\mathrm{CP}_{100}$ and $\mathrm{CP}_{200}$. The compostamended treatments resulted in higher $\mathrm{CP}$ degradation at each stage of incubation, which was also higher than the degradation observed in controls (unamended treatments $\mathrm{CP}_{100}$ and $\mathrm{CP}_{200}$ ). The biochar-amended treatments showed reduced $\mathrm{CP}$ degradation relative to the unamended soils. At the end of the incubation period, 98 and $89 \%$ of $\mathrm{CP}$ was degraded for $\mathrm{CP}_{100}+\mathrm{FC}$ and $\mathrm{CP}_{200}+\mathrm{FC}$, which was an 87 and $65 \%$ higher degradation than observed for the unamended $\left(\mathrm{CP}_{100}\right.$ and $\left.\mathrm{CP}_{200}\right)$ controls. In comparison, only 76 and $59 \%$ of $\mathrm{CP}$ was degraded with treatments $\mathrm{CP}_{100}+\mathrm{WSB}$ and $\mathrm{CP}_{200}+\mathrm{WSB}$, respectively. The compost amendment significantly (ANOVA: $p=0.000$ ) reduced the half-lives of $\mathrm{CP}$ from 40 and 68 days with $\mathrm{CP}_{100}$ and $\mathrm{CP}_{200}$, respectively, to 20 and 37 days with $\mathrm{CP}_{100}+\mathrm{FC}$ and $\mathrm{CP}_{200}+\mathrm{FC}$, respectively (Table 1 ). Among all the treatments the highest $\mathrm{CP}$ degradation rate (K) $\left(0.034 \mathrm{mg} \mathrm{kg}^{-1} \mathrm{~d}^{-1}\right)$ was achieved with $\mathrm{CP}_{100}+\mathrm{FC}$.

In contrast to the NSS, for the SS, at both initial CP concentrations of 100 and $200 \mathrm{mg} \mathrm{kg}^{-1}$ (Figure 3), all compost and biochar treatments inhibited (decreased) the degradation of $\mathrm{CP}$ at all stages of incubation compared to the $\mathrm{CP}_{100}$ and $\mathrm{CP}_{200}$ (unamended treatments) controls. Thus, treatments $\mathrm{CP} 100+\mathrm{FC}, \mathrm{CP}_{100}+\mathrm{WSB}, \mathrm{CP}_{200}+\mathrm{FC}$ and $\mathrm{CP}_{200}+\mathrm{WSB}$ showed $48,87,24$ and $50 \%$ less $\mathrm{CP}$ degradation, respectively, compared to the controls $\left(\mathrm{CP}_{100}\right.$ and $\left.\mathrm{CP}_{200}\right)$ at the end of the incubation period. All the amended treatments showed significantly (ANOVA: $p=0.000$ ) longer half-lives and less degradation rates than observed for unamended controls (Table 1). Thus, overall, much higher half-lives and lower degradation rates were found in all treatments with sterilized soil compared to the non-sterilized soil (Figures 2 and 3). 


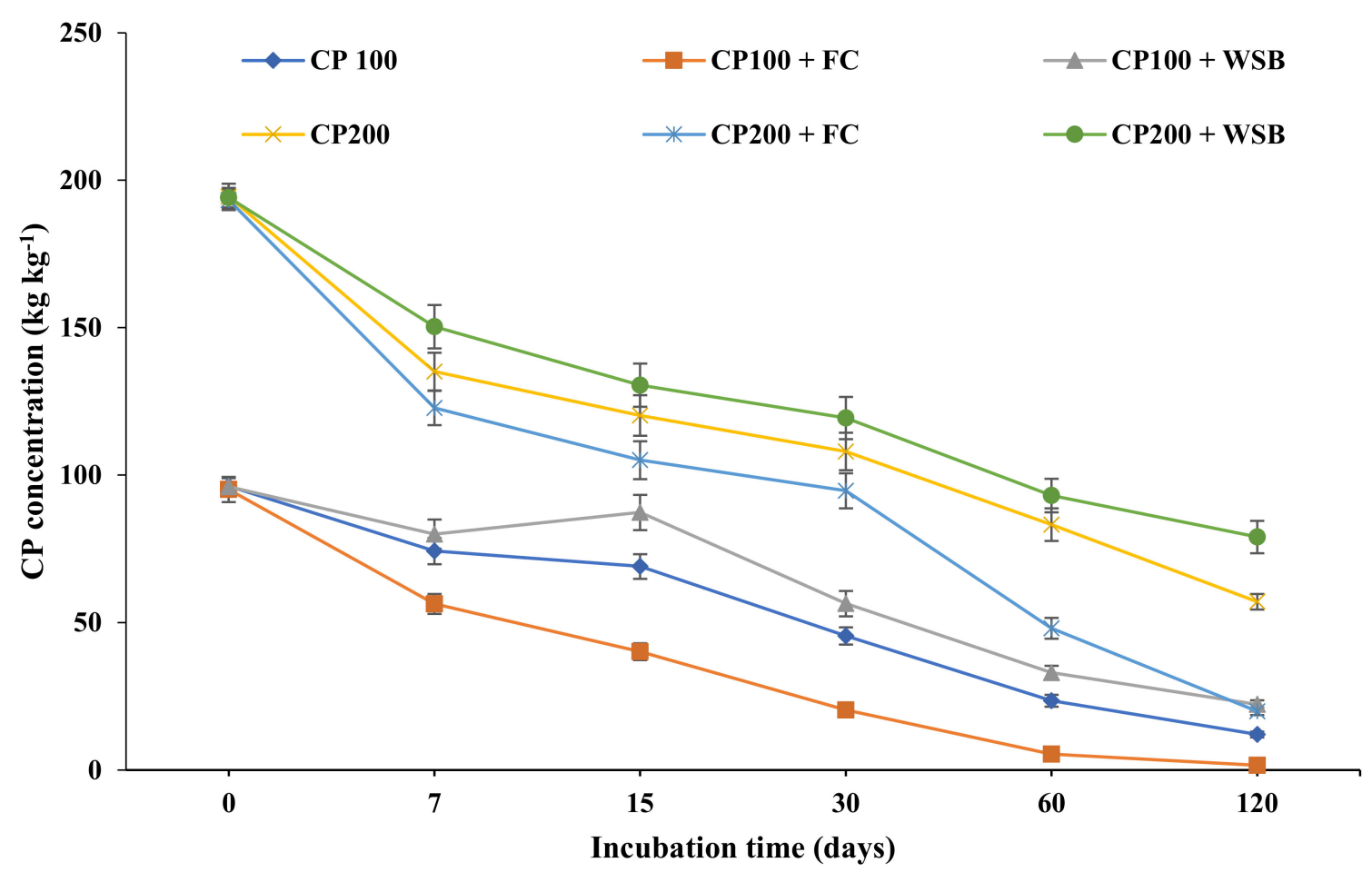

Figure 2. Effect of compost and biochar on the degradation of chlorpyrifos $(\mathrm{CP})$ at two different initial $\mathrm{CP}$ concentrations (100 and $200 \mathrm{mg} \mathrm{kg}^{-1}$ ) in non-sterilized soil. CP: chlorpyrifos, FC: fresh compost, WSB: wheat straw biochar. $\mathrm{CP}_{100}=\mathrm{CP}$ $100 \mathrm{mg} \mathrm{kg}^{-1}, \mathrm{CP}_{100}+\mathrm{FC}=\mathrm{CP} 100 \mathrm{mg} \mathrm{kg}^{-1}+$ fresh compost $0.50 \%, \mathrm{CP}_{100}+\mathrm{WSB}=\mathrm{CP} 100 \mathrm{mg} \mathrm{kg}^{-1}+$ Wheat straw biochar $0.50 \%, \mathrm{CP}_{200}=\mathrm{CP} 200 \mathrm{mg} \mathrm{kg}^{-1}, \mathrm{CP}_{200}+\mathrm{FC}=\mathrm{CP} 200 \mathrm{mg} \mathrm{kg}^{-1}+$ fresh compost $0.50 \%, \mathrm{CP}_{200} \mathrm{~B}_{0.25}=\mathrm{CP} 200 \mathrm{mg} \mathrm{kg}^{-1}+\mathrm{Wheat}$ straw biochar $0.50 \%$.

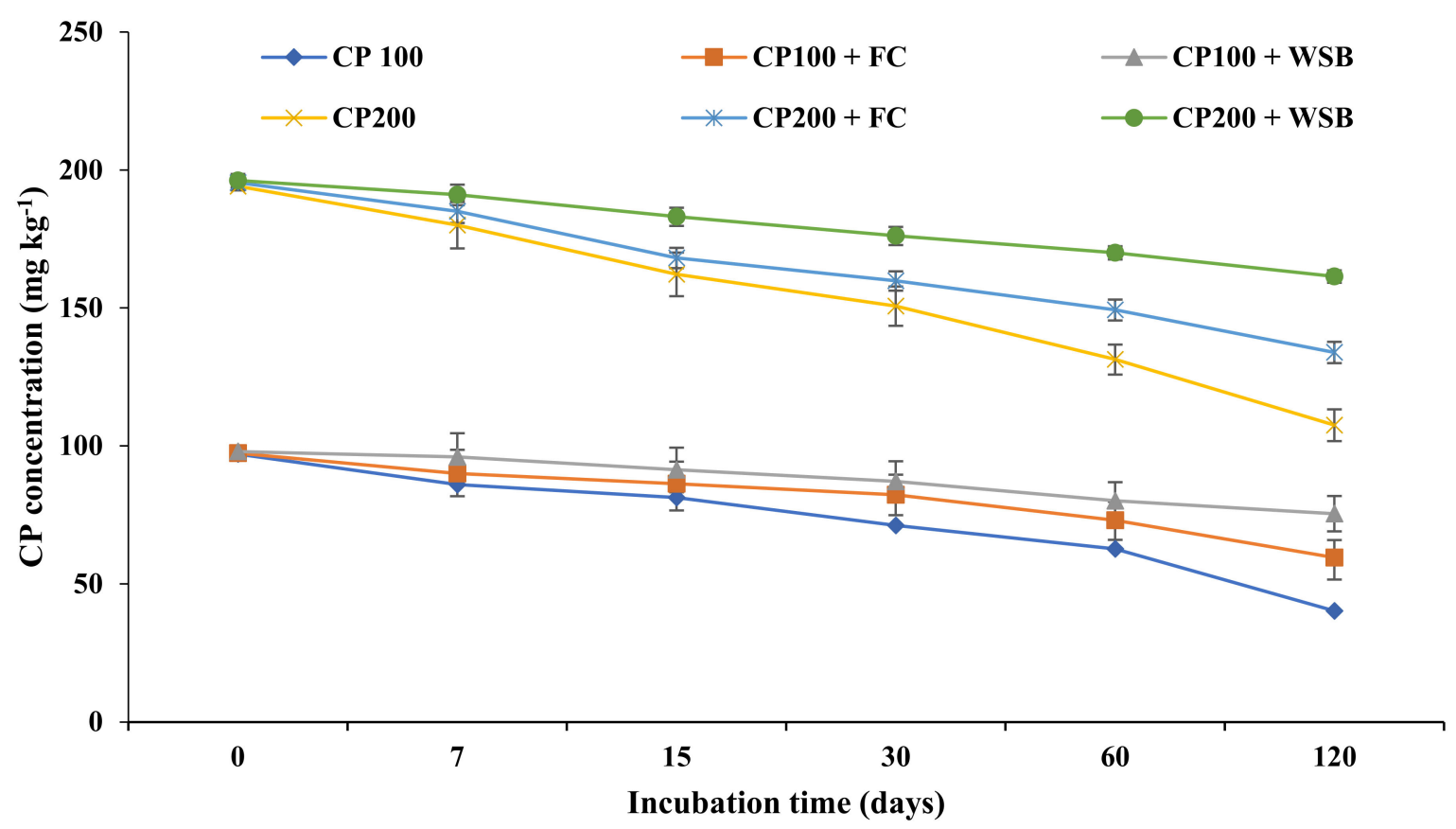

Figure 3. Effect of compost and biochar on the degradation of chlorpyrifos $(\mathrm{CP})$ at two different initial CP concentrations (100 and $200 \mathrm{mg} \mathrm{kg}^{-1}$ ) in sterilized soil. CP: chlorpyrifos, FC: fresh compost, WSB: wheat straw biochar. $\mathrm{CP}_{100}=\mathrm{CP}_{100 \mathrm{mg} \mathrm{kg}}^{-1}$, $\mathrm{CP}_{100}+\mathrm{FC}=\mathrm{CP} 100 \mathrm{mg} \mathrm{kg}^{-1}+$ fresh compost $0.50 \%, \mathrm{CP}_{100}+\mathrm{WSB}=\mathrm{CP} 100 \mathrm{mg} \mathrm{kg}^{-1}+$ Wheat straw biochar $0.50 \%$, $\mathrm{CP}_{200}=\mathrm{CP} 200 \mathrm{mg} \mathrm{kg}^{-1}, \mathrm{CP}_{200}+\mathrm{FC}=\mathrm{CP} 200 \mathrm{mg} \mathrm{kg}{ }^{-1}+$ fresh compost $0.50 \%, \mathrm{CP}_{200} \mathrm{~B}_{0.25}=\mathrm{CP} 200 \mathrm{mg} \mathrm{kg}^{-1}+\mathrm{Wheat}$ straw biochar $0.50 \%$. 


\subsection{Influence of Compost and Biochar on Soil Enzymes Activities under Chlorpyrifos Contamination}

\subsubsection{Soil Dehydrogenase Activity}

The effect of $\mathrm{CP}$ on soil dehydrogenase activity in unamended and amended soils during incubation over 120 days is shown in Figure 4. The main and interaction effects between treatments and time intervals is presented in Supplementary Data Table S6. At both dose levels, $\mathrm{CP}_{100}$ and $\mathrm{CP}_{200}, \mathrm{CP}$ significantly (ANOVA: $p=0.000$ ) reduced the dehydrogenase activity, and at the start of the incubation period, a 79 and $92 \%$ reduction in enzyme activity was observed, respectively. Across all treatments (except control) dehydrogenase activity decreased rapidly in the first 15 days before stabilizing and slowly increasing as incubation proceeded. The inhibiting effect of $\mathrm{CP}$ on dehydrogenase activity significantly increased with increasing CP concentration ( $\left.200 \mathrm{mg} \mathrm{kg}^{-1}\right)$, and at this $\mathrm{CP}$ concentration, the dehydrogenase activity did not recover significantly at the end of the incubation period. For both unamended and amended contaminated treatments, the maximum decrease was recorded at day 15 , and the minimum dehydrogenase activity $\left(1.02 \mu \mathrm{g} \mathrm{TPF} \mathrm{g}^{-1}\right.$ soil $\left.12 \mathrm{~h}^{-1}\right)$ was recorded with $\mathrm{CP}_{200}$ among the unamended treatments and $\left(3.94 \mu \mathrm{g} \mathrm{TPF} \mathrm{g}{ }^{-1}\right.$ soil $\left.12 \mathrm{~h}^{-1}\right)$ with $\mathrm{CP}_{200}+\mathrm{WSB}$ among the amended treatments. A significant reduction in the enzyme activity suppression was observed with both biochar and compost throughout the incubation period, and with treatment $\mathrm{CP} 100+\mathrm{FC}$, even higher enzyme activities were recorded compared to the control soil $\left(\mathrm{CP}_{0} \mathrm{~B}_{0} \mathrm{C}_{0}\right)$ at each stage of incubation, showing the highest enzyme activity $\left(20.97 \mu \mathrm{g}\right.$ TPF g ${ }^{-1}$ soil $\left.12 \mathrm{~h}^{-1}\right)$ at day 120 . Overall, compost-amended contaminated treatments showed significantly high (ANOVA: $p=0.000$ ) dehydrogenase activities over biochar amended ones at each stage of incubation.

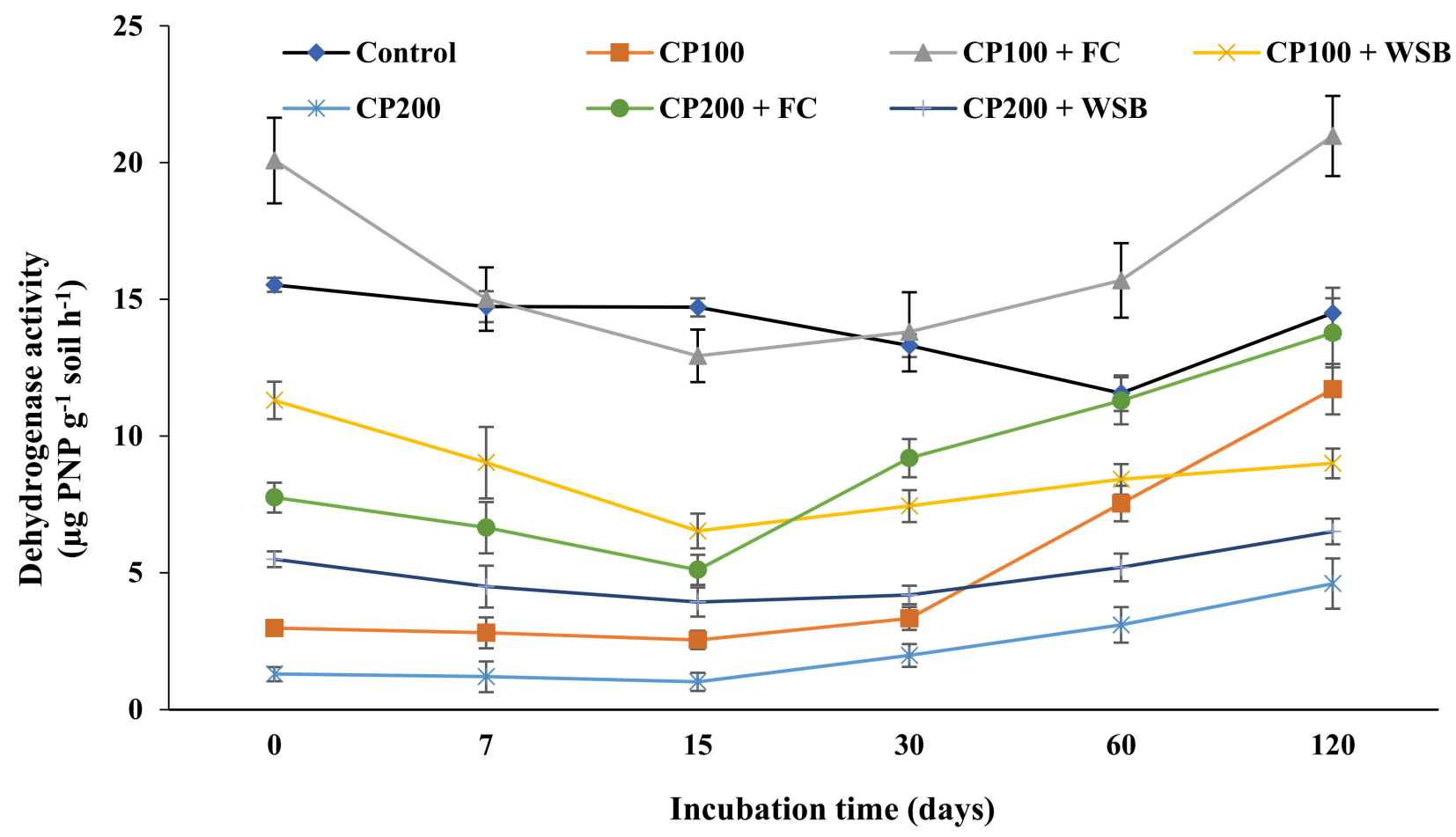

Figure 4. Effect of compost and biochar on soil dehydrogenase activity at two different initial CP concentrations (100 and $\left.200 \mathrm{mg} \mathrm{kg}^{-1}\right)$. CP: chlorpyrifos, FC: fresh compost, WSB: wheat straw biochar. Control $=($ only soil $), \mathrm{CP} 100=\mathrm{CP}$ $100 \mathrm{mg} \mathrm{kg}^{-1}, \mathrm{CP}_{100}+\mathrm{FC}=\mathrm{CP} 100 \mathrm{mg} \mathrm{kg}{ }^{-1}+$ fresh compost $0.50 \%, \mathrm{CP}_{100}+\mathrm{WSB}=\mathrm{CP} 100 \mathrm{mg} \mathrm{kg}^{-1}+$ Wheat straw biochar $0.50 \%, \mathrm{CP}_{200}=\mathrm{CP} 200 \mathrm{mg} \mathrm{kg}^{-1}, \mathrm{CP}_{200}+\mathrm{FC}=\mathrm{CP} 200 \mathrm{mg} \mathrm{kg}^{-1}+$ fresh compost $0.50 \%, \mathrm{CP}_{200} \mathrm{~B}_{0.25}=\mathrm{CP} 200 \mathrm{mg} \mathrm{kg}^{-1}+\mathrm{Wheat}$ straw biochar $0.50 \%$. 


\subsubsection{Soil Urease Activity}

The effect of $\mathrm{CP}$ on soil urease activity in the unamended and amended soils over an incubation period of 120 days is shown in Figure 5. CP negatively affected soil urease activity at both initial $\mathrm{CP}$ concentrations $\left(\mathrm{CP}_{100}\right.$ and $\left.\mathrm{CP}_{200}\right)$ throughout the incubation period. The decrease in urease activity was maximum at day 15 with reductions of 79 and $90 \%$ for $\mathrm{CP}_{100}$ and $\mathrm{CP}_{200}$, respectively, relative to the control $\left(\mathrm{CP}_{0} \mathrm{~B}_{0} \mathrm{C}_{0}\right)$. After day 15 urease activity gradually increased across the incubation period. At both initial $\mathrm{CP}$ concentrations of 100 and $200 \mathrm{mg} \mathrm{kg}^{-1}$, the compost and biochar significantly (ANOVA: $p=0.000$ ) reduced the negative effects of $\mathrm{CP}$ on soil urease activity, where the effect was more evident for the treatment CP100 + FC. However, in all treatments, urease activities remained lower than the activity observed in the control $\left(\mathrm{CP}_{0} \mathrm{~B}_{0} \mathrm{C}_{0}\right)$ soil (over the whole incubation period), except for $\mathrm{CP} 100+\mathrm{FC}$ at the last stage of incubation, at which time urease activity was 28 and $70 \%$ higher than in the control and unamended contaminated treatments $\left(\mathrm{CP}_{100}\right)$, respectively. Amongst the amended contaminated treatments, maximum urease activities (15.6 and $23.4 \mu \mathrm{g} \mathrm{NH}^{4+}-\mathrm{N} \mathrm{g}^{-1} \mathrm{~h}^{-1}$ ) were observed for $\mathrm{CP} 100+\mathrm{FC}$ at day 0 and 120, respectively, and minimum urease activities (6.14 and $\left.7.72 \mu \mathrm{g} \mathrm{NH} \mathrm{N}^{4+}-\mathrm{N} \mathrm{g}^{-1} \mathrm{~h}^{-1}\right)$ were recorded with CP200 + WSB at day 0 and 120, respectively.

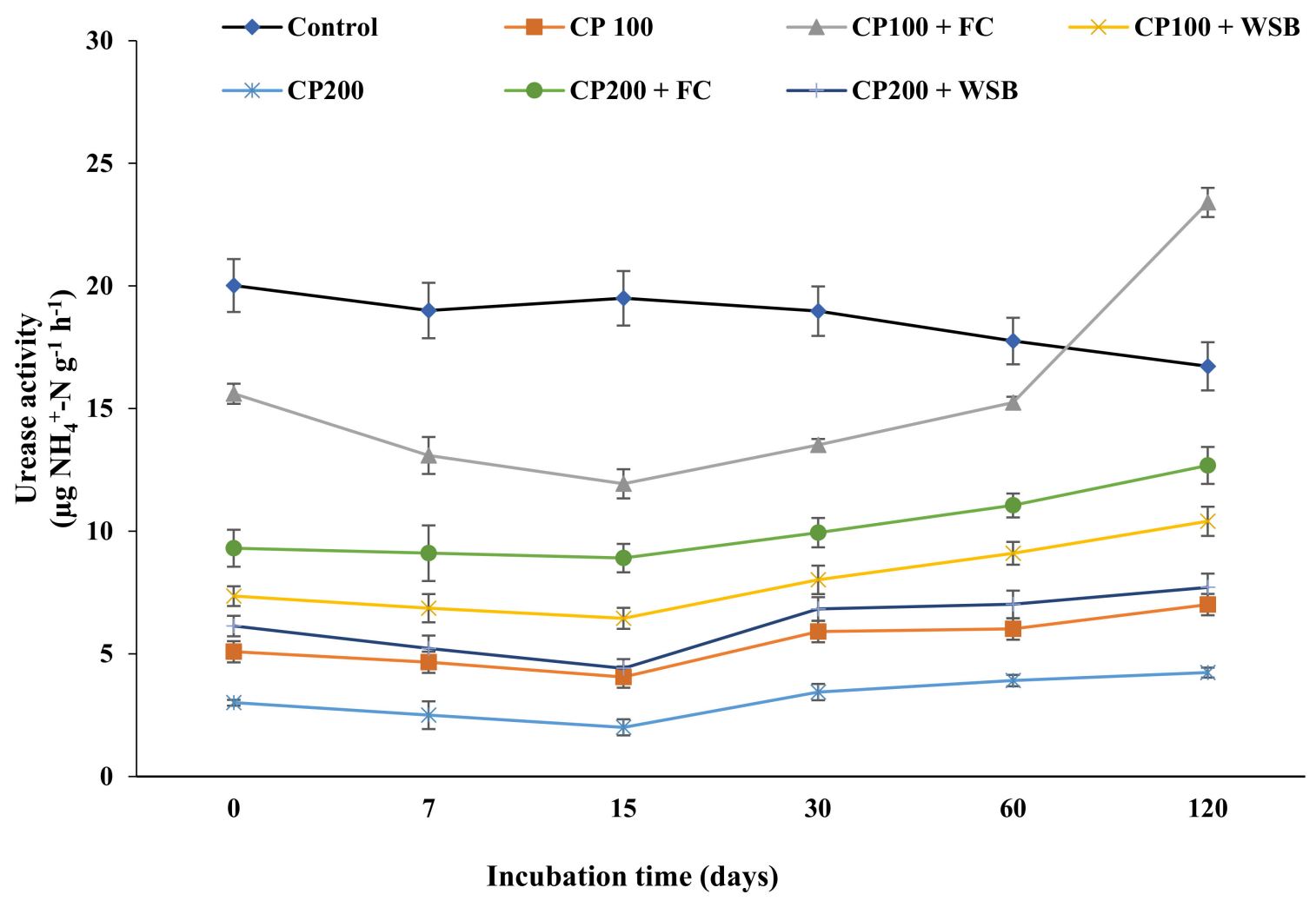

Figure 5. Effect of compost and biochar on soil urease activity at two different initial CP concentrations (100 and $200 \mathrm{mg} \mathrm{kg}^{-1}$ ). CP: chlorpyrifos, FC: fresh compost, WSB: wheat straw biochar. Control = (only soil), $\mathrm{CP}_{100}=\mathrm{CP}_{100 \mathrm{mg} \mathrm{kg}}^{-1}$, $\mathrm{CP}_{100}+\mathrm{FC}=\mathrm{CP} 100 \mathrm{mg} \mathrm{kg}{ }^{-1}+$ fresh compost $0.50 \%, \mathrm{CP}_{100}+\mathrm{WSB}=\mathrm{CP} 100 \mathrm{mg} \mathrm{kg}^{-1}+$ Wheat straw biochar $0.50 \%$, $\mathrm{CP}_{200}=\mathrm{CP} 200 \mathrm{mg} \mathrm{kg}^{-1}, \mathrm{CP}_{200}+\mathrm{FC}=\mathrm{CP} 200 \mathrm{mg} \mathrm{kg}^{-1}+$ fresh compost $0.50 \%, \mathrm{CP}_{200} \mathrm{~B}_{0.25}=\mathrm{CP} 200 \mathrm{mg} \mathrm{kg}^{-1}+\mathrm{Wheat}$ straw biochar $0.50 \%$.

\subsubsection{Soil Phosphatase Activity}

The effect of $\mathrm{CP}$ on soil phosphatase activity in unamended and amended soils during the incubation period of 120 days is shown in Figure 6. In the unamended contaminated soil, the phosphatase activity was significantly (ANOVA: $p=0.000$ ) reduced by $\mathrm{CP}$ at the start of incubation period, with 60 and $87 \%$ less phosphatase activity ( 3 and $1 \mu \mathrm{g} \mathrm{TPF} \mathrm{g}^{-1}$ soil $12 \mathrm{~h}^{-1}$ ) for $\mathrm{CP}_{100}$ and $\mathrm{CP}_{200}$, respectively, compared to $\mathrm{CP}_{0} \mathrm{~B}_{0} \mathrm{C}_{0}$ 
(7.5 $\mu$ g PNP g ${ }^{-1}$ soil h$^{-1}$ ). At both dose levels, 100 and $200 \mathrm{mg} \mathrm{kg}^{-1}$, significantly (ANOVA: $p=0.000$ ) higher phosphatase activities were observed with the application of compost and biochar amendments. However, with compost $(\mathrm{CP} 100+\mathrm{FC})$, these activities were even higher (ANOVA: $p=0.000)$ than the uncontaminated control soil $\left(\mathrm{CP}_{0} \mathrm{~B}_{0} \mathrm{C}_{0}\right)$ at the last two stages of incubation. In all amended and unamended contaminated treatments, the phosphatase activity initially decreased to day 15 , and thereafter, it stabilized and slowly increased until the end of incubation. Amongst all treatments the maximum phosphatase activities $\left(8.13 \mu \mathrm{g} \mathrm{PNPg}^{-1}\right.$ soil h$\left.^{-1}\right)$ and $\left(14.01 \mu \mathrm{g} \mathrm{PNP} \mathrm{g}^{-1}\right.$ soil h$\left.^{-1}\right)$ were observed with CP100 + FC at day 0 and 120, respectively, and the minimum phosphatase activities $\left(1 \mu \mathrm{g} \mathrm{PNP} \mathrm{g}{ }^{-1}\right.$ soil $\left.^{-1}\right)$ and $\left(3.02 \mu \mathrm{g} \mathrm{PNP} \mathrm{g}{ }^{-1}\right.$ soil $\left.^{-1}\right)$ were observed with CP200 at day 0 and 120 , respectively.

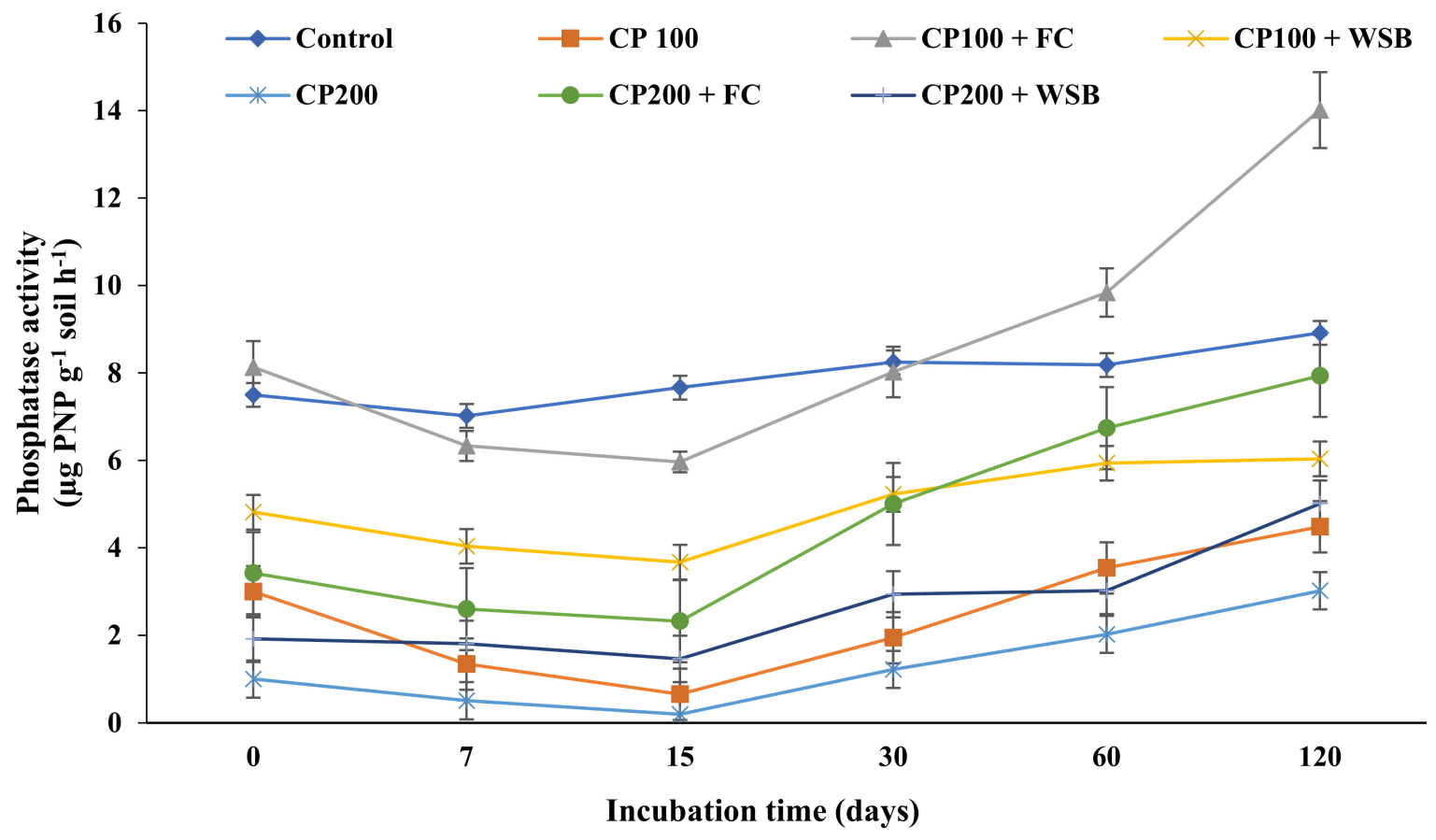

Figure 6. Effect of compost and biochar on soil phosphatase activity at two different initial CP concentrations (100 and

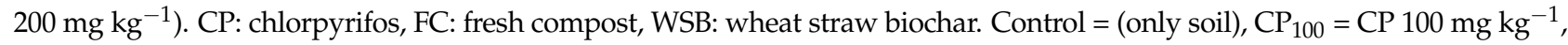
$\mathrm{CP}_{100}+\mathrm{FC}=\mathrm{CP} 100 \mathrm{mg} \mathrm{kg}^{-1}+$ fresh compost $0.50 \%, \mathrm{CP}_{100}+\mathrm{WSB}=\mathrm{CP} 100 \mathrm{mg} \mathrm{kg}^{-1}+$ Wheat straw biochar $0.50 \%$, $\mathrm{CP}_{200}=\mathrm{CP} 200 \mathrm{mg} \mathrm{kg}^{-1}, \mathrm{CP}_{200}+\mathrm{FC}=\mathrm{CP} 200 \mathrm{mg} \mathrm{kg}^{-1}+$ fresh compost $0.50 \%, \mathrm{CP}_{200} \mathrm{~B}_{0.25}=\mathrm{CP} 200 \mathrm{mg} \mathrm{kg}^{-1}+\mathrm{Wheat}_{\mathrm{straw}}$ biochar $0.50 \%$.

\section{Discussion}

The most important factor affecting the fate and distribution of pesticides in soil is sorption [43]. Compared to the unamended soil, CP degradation was significantly reduced in biochar amended soils at both initial $\mathrm{CP}$ concentrations. This was attributed to the strong sorption of $\mathrm{CP}$ to the biochar amended soil and, consequently, less desorption from the added organic amendment [27] leading towards lower CP bioavailability [39]. Organic matter added to a soil provides one of the most important sorbent surfaces for the non-polar pesticides of low water solubility because phase partitioning is driven by hydrophobic interactions $[44,45]$. Of the many different types of organic matter, the microporosity, high specific surface area and large number of functional groups on the biochar's surface [46] makes it a very efficient sorbent material for a variety of synthetic organic contaminants. Significant decreases in the degradation of $\mathrm{CP}$ in soil following the addition of biochar has been previously reported [33]. The decreased degradation of $\mathrm{CP}$ in biochar-amended soil could also be attributed to the diffusion of pesticides into 
the soil-organic amendment mixture and to the nano-pores introduced by amendments directly resulting in less availability of the pesticide for biodegradation [47].

In contrast to the biochar-amended soil, the compost-amended soil increased CP degradation compared to the unamended soil. A variety of organic amendments have been proposed previously as options to enhance pesticides degradation such as peanut shells, farm-yard manure, coconut husks, T. diversifolia leaves, etc. [48-50]. Dehydrogenase enzyme activity is usually a good measure of potential degradation efficiency [49] and increased dehydrogenase activity on the application of compost in this study suggested that compost provided more degradation capacity than biochar. Moreover, compost provides labile carbon in large amounts, which microbes can use as a substrate food source [23]. The indigenous microbes in the organic material secrete extracellular enzymes which can boost up the degradation of organic pollutants by rendering their hydrophobic parts hydrophilic in nature and inducing some alteration in their composition [51,52].

Compared to the NSS, significantly less CP degradation occurred in the SS in both unamended and amended treatments with either biochar and/or compost. These results were in agreement with [23], who showed reduced pesticides degradation under sterilized conditions compared to non-sterile conditions in soil, and by [53] in an unamended forest soil. Increased pesticide degradation was correlated with increased microbial activity in NSS, which, unlike SS, had not had its innate microbial population decimated by autoclaving. Sterilization significantly extended the half-lives of $\mathrm{CP}$ with less degradation compared to NSS at both initial concentrations. These results were previously supported by [54].

$\mathrm{CP}$ degradation was more inhibited (lower degradation rate; longer half-lives) for $\mathrm{CP}_{200}$ compared to $\mathrm{CP}_{100}$ throughout the incubation in both amended and unamended soils. A reduced degradation efficiency with increasing $\mathrm{CP}$ concentration was previously reported by $[55,56]$ in an organic mixture and by [57] in a soil. At higher $\mathrm{CP}$ concentrations, one of $\mathrm{CP}^{\prime}$ 's main metabolites, 3,5,6-trichloro-2-pyridinol (TCP), starts to increase in concentration and could be a cause of CP-reduced degradation $[58,59]$.

Soil enzyme activity is a key biochemical factor assessing soil quality due to its sensitivity to toxicity and disturbances [60]. In agreement with previous findings [47,61-63], the results of this study indicated that $\mathrm{CP}$ inhibited soil dehydrogenase, urease and phosphatase activities. In the CP-contaminated soil, the maximum reduction in dehydrogenase, urease and phosphatase activities was observed at day 15 of the incubation, which was in agreement with a previous study [47]. The decrease in soil enzyme activities in CP spiked soils could be attributed to the increased microbial toxicity of byproducts formed during degradation [28]. The recoveries of enzyme activities in the later stages of incubation may be due to significant pesticide loss via degradation, thus reducing pesticide toxicity $[47,53]$ and recovery of microbial growth as manifested by the alleviated soil enzymes activities in our results.

We reported the comparative behavior of compost and biochar in alleviation of soil enzymes activities under $\mathrm{CP}$ pollution, which is lacking in previous studies. According to the results of our findings, although both amendments showed a reduction in the suppression of all soil enzymes activities, compost proved to be significantly effective as compared to biochar in this regard. In fact, when compost was added to the CP contaminated soil, enzyme activities were even greater than in the uncontaminated treatments pronouncedly at later stages of incubation. The accelerating effect of compost on soil enzymes' activities may be due to the introduction of new microbial communities [64], which may be responsible for the production of extracellular enzymes capable of degrading $\mathrm{CP}$. We found significantly higher soil dehydrogenase, urease and phosphatase enzymes activities and degradation of $\mathrm{CP}$ in compost-amended treatments compared to the biochar at each stage of incubation (Figure 2). Moreover, the mechanism of compost introduced enzymatic secretions in accelerating the $\mathrm{CP}$ degradation need to be explored. 


\section{Conclusions}

The degradation of CP in biochar- and compost-amended and unamended soils followed first order kinetics. CP at a $200 \mathrm{mg} \mathrm{kg}^{-1}$ dose exhibited significantly lower degradation rate and increased half-life compared to a $100 \mathrm{mg} \mathrm{kg}^{-1}$ dose, indicating restricted degradation at higher doses. The reduced degradation may be attributed to the accumulation of its metabolites at high concentration as manifested by the enhanced negative effect on soil enzymes activities at a higher dose in our finding. The application of compost increased CP degradation. The activities of soil enzymes were severely affected by the CP contamination pronouncedly at the initial stages of incubation, and both compost and biochar proved to be effective in alleviating the adverse effects of CP on the activities of these soil enzymes. Compost-amended soils exhibited higher enzyme activities than the uncontaminated soil, even in the presence of high concentrations of CP, especially at the later stages of incubation. Thus, the co-application of both biochar and compost is an important strategy to mitigate the adverse effects of CP. However, compost addition could be more effective for the abatement of $\mathrm{CP}$ residues from contaminated soils having accelerating effect on CP degradation.

Supplementary Materials: The following are available online at https: / www.mdpi.com/article / 10.3390/su13179695/s1. Table S1: Selected physicochemical properties of the soil and amendments used in the study, Table S2: Treatment description and their abbreviations used in the study, Table S3: LSD-Main and Interaction effects (between time interval and treatments) for Chlorpyrifos degradation in non-sterilized and sterilized soil, Table S4: Two-way Analysis of Variance Table for Chlorpyrifos degradation in non-sterilized soil, Table S5: Two-way Analysis of Variance Table for Chlorpyrifos degradation in sterilized soil, Table S6: LSD- Main and Interaction effects (between time interval and treatments) for soil enzymes activities, Table S7: Two way Analysis of Variance Table for Dehydrogenase activity, Table S8: Two-way Analysis of Variance Table for Urease activity, Table S9: Two-way Analysis of Variance Table for Phosphatase activity, Table S10: Completely randomized Analysis of Variance Table for Chlorpyrifos half lives in non-sterilized soil, Table S11: Completely randomized Analysis of Variance Table for Chlorpyrifos half lives in sterilized soil.

Author Contributions: Conceptualization, H.A., X.W., G.M., M.H.S., S.F. and S.A.; data curation, H.A., A.A., M.A. and B.M.; formal analysis, H.A., A.A., S.H. and B.M.; funding acquisition, X.W. and G.M.; investigation, H.A., G.M., S.H., B.M. and S.A.; methodology, H.A., A.A., S.H., M.A. and B.M.; project administration, G.M.; resources, X.W., G.M. and S.A.; software, M.A., M.H.S., S.F. and S.A.; supervision, G.M.; Validation, A.A. and S.H.; visualization, S.H.; writing-original draft, H.A. and S.F.; writing-review and editing, X.W., G.M., M.H.S. and S.A. All authors have read and agreed to the published version of the manuscript.

Funding: The principal author is highly thankful to the Higher Education Commission (HEC), Pakistan, for granting a Ph.D. Indigenous scholarship (PIN NO. 213-63298-2AV2-101) to financially support this research work. The publication of the present work is supported by the Natural Science Basic Research Program of Shaanxi Province (grant no. 2018JQ5218) and the National Natural Science Foundation of China (51809224), Top Young Talents of Shaanxi Special Support Program.

Institutional Review Board Statement: Not applicable.

Informed Consent Statement: Not applicable.

Data Availability Statement: Not applicable.

Acknowledgments: The authors are highly thankful to the Higher Education Commission (HEC), Pakistan for granting Ph.D. Indigenous scholarship to the principal author for this research work. Special thanks to the Pesticide Residue laboratory Kala Shah Kaku, Sheikhupura, Pakistan, for providing GC-MS facility for the analysis of samples. The publication of the present work is supported by the Natural Science Basic Research Program of Shaanxi Province (grant no. 2018JQ5218) and the National Natural Science Foundation of China (51809224), Top Young Talents of Shaanxi Special Support Program.

Conflicts of Interest: The authors declare no conflict of interest. 


\section{References}

1. Silva, V.; Mol, H.G.; Zomer, P.; Tienstra, M.; Ritsema, C.J.; Geissen, V. Pesticide residues in European agricultural A hidden reality unfolded. Sci. Total Environ. 2019, 653, 1532-1545. [CrossRef]

2. Wang, X.; Wang, G.; Guo, T.; Xing, Y.; Mo, F.; Wang, H.; Fan, J.; Zhang, F. Effects of plastic mulch and nitrogen fertilizer on the soil microbial community, enzymatic activity and yield performance in a dryland maize cropping system. Eur. J. Soil Sci. 2021, 72, 400-412. [CrossRef]

3. Wang, X.; Fan, J.; Xing, Y.; Xu, G.; Wang, H.; Deng, J.; Wang, Y.; Zhang, F.; Li, P.; Li, Z. The effects of mulch and nitrogen fertilizer on the soil environment of crop plants. Adv. Agron. 2019, 153, 121-173.

4. Chai, L.; Wong, M.; Hansen, H.C.B. Degradation of chlorpyrifos in humid tropical soils. J. Environ. Manag. 2013, 125, 28-32. [CrossRef]

5. Lu, P.; Li, Q.; Liu, H. Biodegradation of chlorpyrifos and 3,5,6-trichloro-2-pyridinol by Cupriavidus sp. DT-1. Bioresour. Technol. 2013, 127, 337-342. [CrossRef]

6. Skevas, T. Evaluating alternative policies to reduce pesticide groundwater pollution in Dutch arable farming. J. Environ. Plan. Manag. 2020, 63, 733-750. [CrossRef]

7. Chishti, Z.; Arshad, M. Growth Linked Biodegradation of Chlorpyrifos by 470 Agrobacterium and Enterobacter spp. Int. J. Agric. Biol. 2013, 15, 19-26.

8. Howard, P.H.; Gray, D.A.; Sage, G.W.; Jarvis, W.F. Handbook of Environmental Fate and Exposure Data: For Organic Chemicals; Volume II: Solvents; CRC Press: Boca Raton, FL, USA, 1990; Volume IV.

9. Brogan, W.R.; Relyea, R.A. Multiple mitigation mechanisms: Effects of submerged plants on the toxicity of nine insecticides to aquatic animals. Environ. Pollut. 2017, 220, 688-695. [CrossRef]

10. Gomez-Gimenez, B.; Llansola, M.; Hernandez-Rabaza, V.; Cabrera-Pastor, A.; Malaguarnera, M.; Agusti, A.; Felipo, V. Sexdependent effects of developmental exposure to different pesticides on spatial learning. The role of induced neuroinflammation in the hippocampus. Food Chem. Toxicol. 2017, 99, 135-148. [CrossRef]

11. Wang, P.; Wang, J.; Sun, Y.J.; Yang, L.; Wu, Y.J. Cadmium and chlorpyrifos inhibit cellular immune response in spleen of rats. Environ. Toxicol. 2017, 32, 1927-1936. [CrossRef]

12. Rahman, H.U.; Asghar, W.; Nazir, W.; Sandhu, M.A.; Ahmed, A.; Khalid, N. A comprehensive review on chlorpyrifos toxicity with special reference to endocrine disruption: Evidence of mechanisms, exposures and mitigation strategies. Sci. Total Environ. 2020, 755, 142649. [CrossRef]

13. Ishaq, M.; Sultana, N.; Ikram, M.; Iqbal, A.; Shah, F.; Hamayun, M.; Hussain, A. Occurrence of heavy metals and pesticide residues in tomato crop: A threat to public health. Arab. J. Geosci. 2020, 13, 627. [CrossRef]

14. Bose, S.; Kumar, P.S.; Vo, D.V.N. A review on the microbial degradation of chlorpyrifos and its metabolite TCP. Chemosphere 2021, 283, 31447. [CrossRef]

15. Nekooie, R.; Shamspur, T.; Mostafavi, A. Novel CuO/TiO2/PANI nanocomposite: Preparation and photocatalytic investigation for chlorpyrifos degradation in water under visible light irradiation. J. Photochem. Photobiol. Chem. 2021, 407, 113038. [CrossRef]

16. Yu, H.; Zeng, G.; Huang, H.; Xi, X.; Wang, R.; Huang, D.; Li, J. Microbial community succession and lignocellulose degradation during agricultural waste composting. Biodegradation 2007, 18, 793-802. [CrossRef]

17. Ahmad, M.; Rajapaksha, A.U.; Lim, J.E.; Zhang, M.; Bolan, N.; Mohan, D.; Ok, Y.S. Biochar as a sorbent for contaminant management in soil and water: A review. Chemosphere 2017, 99, 19-33. [CrossRef] [PubMed]

18. Wu, H.; Zeng, G.; Liang, J.; Chen, J.; Xu, J.; Dai, J.; Wan, J. Responses of bacterial community and functional marker genes of nitrogen cycling to biochar, compost and combined amendments in soil. Appl. Microbiol. Biotech. 2017, 100, 8583-8591. [CrossRef]

19. Su, C.C.; Ma, J.F.; Chen, Y.P. Biochar can improve the soil quality of new creation farmland on the Loess Plateau. Environ. Sci. Pollut. Res. 2019, 26, 2662-2670. [CrossRef] [PubMed]

20. Gaonkar, O.D.; Nambi, I.M.; Govindarajan, S.K. Soil organic amendments: Impacts on sorption of organophosphate pesticides on an alluvial soil. J. Soils Sed. 2019, 19, 566-578. [CrossRef]

21. Garcia-Jaramillo, M.; Cox, L.; Cornejo, J.; Hermosín, M.C. Effect of soil organic amendments on the behavior of bentazone and tricyclazole. Sci. Total Environ. 2014, 466, 906-913. [CrossRef] [PubMed]

22. Tang, X.; Huang, W.; Guo, J.; Yang, Y.; Tao, R.; Xu, F. Use of Fe-impregnated Biochar to Efficiently Sorb Chlorpyrifos, reduce uptake by Allium fistulosum L. and Enhance Microbial Community diversity. J. Agric. Food Chem. 2017, 65, 5238-5243. [CrossRef] [PubMed]

23. Garcia-Jaramillo, M.; Cox, L.; Hermosín, M.C.; Cerli, C.; Kalbitz, K. Influence of green waste compost on azimsulfuron dissipation and soil functions under oxic and anoxic conditions. Sci. Total Environ. 2016, 550, 760-767. [CrossRef]

24. Luo, F.Z.; Xiang, L.; Li, H. Effects of arbuscular mycorrhizal fungi (AMF) on growth and Cd accumulation of upland rice and soil enzyme activities in cadmium contaminated soil. J. Agro-Environ. Sci. 2015, 34, 1090-1095. [CrossRef]

25. Wu, H.; Lai, C.; Zeng, G.; Liang, J.; Chen, J.; Xu, J.; Lu, L. The interactions of composting and biochar and their implications for soil amendment and pollution remediation: A review. Crit. Rev. Biotechnol. 2017, 754-764. [CrossRef] [PubMed]

26. Feng, F.; Ge, J.; Li, Y.; Cheng, J.; Zhong, J.; Yu, X. Isolation, colonization, and chlorpyrifos degradation mediation of the endophytic bacterium Sphingomonas strain HJY in Chinese Chives (Allium tuberosum). J. Agric. Food Chem. 2017, 65, 1131-1138. [CrossRef] [PubMed] 
27. Cederlund, H.; Borjesson, E.; Stenstrom, J. Effects of a wood-based biochar on the leaching of pesticides chlorpyrifos, diuron, glyphosate and MCPA. J. Environ. Manag. 2017, 191, 28-34. [CrossRef]

28. Jastrzebska, E. The Effect of Chlorpyrifos and Teflubenzuron on the Enzymatic Activity of Soil. Pol. J. Environ. Stud. 2011, 20, 903-910.

29. Gianfreda, L.; Rao, M.A.; Piotrowska, A.; Palumbo, G.; Colombo, C. Soil enzyme activities by antropogenic alterations: Intensiv agricultiral practice and organic pollution. Sci. Total Environ. 2005, 341, 265-279. [CrossRef]

30. Sanchez-Hernandez, J.C. Biochar Mitigates the Impact of Pesticides on Soil Enzyme Activities. In Bioremediation of Agricultural Soils; Sanchez-Hernandez, J.C., Ed.; CRC Press: Boca Raton, FL, USA, 2019; pp. 193-216.

31. Sanchez, M.E.; Lindao, E.; Margaleff, D.; Martınez, O.; Moran, A. Pyrolysis of agricultural residues from rape and sunflowers: Production and characterization of bio-fuels and biochar soil management. J. Anal. Appl. Pyrol. 2009, 85, 142-144. [CrossRef]

32. Ahmad, R.; Shahzad, S.M.; Khalid, A.; Arshad, M.; Mahmood, M.H. Growth and yield response of wheat (Triticum aestivum L.) and maize (Zea mays L.) to nitrogen and L-tryptophan enriched compost. Pak. J. Bot. 2007, 39, 541.

33. Yang, X.; Guoying, G.; Anpeng, P.; Zhao, L.J.L.; Zhang, L.J.; Yuan, P.; He, H.P. Influence of Biochar on Plant Uptake and Dissipation of Two Pesticides in an Agricultural Soil. J. Agric. Food Chem. 2010, 58, 7915-7921. [CrossRef]

34. Gaskin, J.W.; Steiner, C.; Harris, K.; Das, K.C.; Bibens, B. Effect of low-temperature pyrolysis conditions on biochar for agricultural use. Trans. ASABE 2008, 51, 2061-2069. [CrossRef]

35. US Salinity Lab Staff. Diagnosis and Improvement of Saline and Alkali Soils; Handbook 60; USDA: Washington, DC, USA, 1954.

36. Yakout, S.M.; Daifullah, A.E.H.M.; El-Reefy, S.A. Pore structure characterization of chemically modified biochar derived from rice straw. Environ. Eng. Manag. J. 2015, 14, 473-480. [CrossRef]

37. Gai, X.; Wang, H.; Liu, J.; Zhai, L.; Liu, S.; Ren, T.; Liu, H. Effects of feedstock and pyrolysis temperature on biochar adsorption of ammonium and nitrate. PLoS ONE 2015, 9, e113888. [CrossRef]

38. Walkley, A.; Black, I.A. An examination of Degtjareff method for determining soil organic matter and a proposed modification of the chromic acid titration method. Soil Sci. 1934, 37, 29-37. [CrossRef]

39. Yu, X.Y.; Ying, G.; Kookana, R.S. Reduced plant uptake of pesticides with biochar additions to soil. Chemosphere 2009, 76, 665-671. [CrossRef] [PubMed]

40. Min, H.; Ye, Y.F.; Chen, Z.Y.; Wu, W.X.; Du, Y.F. Effects of butachlor on microbial populations and enzyme activities in paddy soil. J. Environ. Sci. Health 2001, 36, 581-595. [CrossRef]

41. Kandeler, E.; Gerber, H. Short-term assay of soil urease activity using colorimetric determination of ammonium. Biol. Fertil. Soils 1988, 6, 68-72. [CrossRef]

42. Tabatabai, M.A.; Bremner, J.M. Use of p-nitrophenyl phosphate for assay of soil phosphatase activity. Soil Biol. Biochem. 1969, 1, 301-307. [CrossRef]

43. De Wilde, T.; Spanoghe, P.; Ryckeboer, J.; Jaeken, P.; Springael, D. Sorption characteristics of pesticides on matrix substrates used in biopurification systems. Chemosphere 2009, 75, 100-108. [CrossRef]

44. Hamaker, J.W.; Thompson, J.M. Adsorption of organic chemicals in the soil environment. In Organic Chemicals in the Soil Environment; Hamaker, J.W., Goring, C.A.I., Eds.; Marcel Decker Inc.: New York, NY, USA, 1972; Volume 1, pp. 49-144.

45. Moyo, F.; Tandlich, R.; Wilhelmi, B.S.; Balaz, S. Sorption of hydrophobic organic compounds on natural sorbents and organoclays from aqueous and non-aqueous solutions: A mini-review. Int. J. Environ. Res. Public Health 2014, 11, 5020-5048. [CrossRef]

46. Deng, H.; Feng, D.; He, J.X.; Li, F.Z.; Yu, H.M.; Ge, C.J. Influence of biochar amendments to soil on the mobility of atrazine using sorption-desorption and soil thin-layer chromatography. Ecol. Eng. 2017, 99, 381-390. [CrossRef]

47. Khorram, M.S.; Zheng, Y.; Lin, D.; Zhang, Q.; Fang, H.; Yu, Y. Dissipation of fomesafen in biochar-amended soil and its availability to corn (Zea mays L.) and earthworm (Eiseniafetida). J. Soil Sed. 2016, 16, 2439-2448. [CrossRef]

48. Mutua, G.K.; Ngigi, A.N.; Getenga, Z.M. Chlorpyrifos Degradation in Soils with Different Treatment Regimes within Nzoia River Drainage Basin, Kenya. Bull. Environ. Contam. Toxicol. 2015, 94, 387-392. [CrossRef]

49. Kadian, N.; Malik, A.; Satya, S.; Dureja, P. Effect of organic amendments on microbial activity in chlorpyrifos contaminated soil. J. Environ. Manag. 2012, 95, 199-202. [CrossRef]

50. Romyen, S.; Luepromchai, E.; Hawker, D.; Karnchanasest, B. Potential of agricultural by-product in reducing chlorpyrifos leaching through soil. J. App. Sci. 2007, 7, 2686-2690. [CrossRef]

51. Kravvariti, K.; Tsiropoulos, N.G.; Karpouzas, D.G. Degradation and adsorption of terbuthylazine and chlorpyrifos in biobed biomixtures from composted cotton crop residues. Pest Manag. Sci. 2010, 66, 1122-1128. [CrossRef] [PubMed]

52. Lopez-Pineiro, A.; Cabrera, D.; Albarran, A.; Pena, D. Influence of two-phase olive mill waste application to soil on terbuthylazine behavior and persistence under controlled and field conditions. J. Soils Sed. 2011, 11, 771-782. [CrossRef]

53. Valle, A.; Boschin, G.; Negri, M.; Abbruscato, P.; Sorlini, C.; D'agostina, A.; Zanardini, E. The microbial degradation of azimsulfuron and its effect on the soil bacterial community. J. Appl. Microbiol. 2006, 101, 443-452. [CrossRef]

54. Akbar, S.; Sultan, S. Soil bacteria showing a potential of chlorpyrifos degradation and plant growth enhancement. Braz. J. Microbiol. 2016, 47, 563-570. [CrossRef]

55. Vischetti, C.; Monaci, E.; Cardinali, A.; Casucci, C.; Perucci, P. The effect of initial concentration, co-application and repeated applications on pesticide degradation in a biobed mixture. Chemosphere 2008, 72, 1739-1743. [CrossRef] [PubMed]

56. Tortella, G.R.; Rubilar, O.; Castillo, M.; Cea, M.; Mella-Herrera, R.; Diez, M.C. Chlorpyrifos degradation in a biomixture of biobed at different maturity stages. Chemosphere 2012, 88, 224-228. [CrossRef] [PubMed] 
57. Sardar, D.; Kole, R.K. Metabolism of chlorpyrifos in relation to its effect on the availability of some plant nutrients in soil. Chemosphere 2005, 61, 1273-1280. [CrossRef]

58. Racke, K.D.; Laskowski, D.A.; Schultz, M.R. Resistance of chlorpyrifos to enhanced biodegradation in soil. J. Agric. Food Chem. 1990, 38, 1430-1436. [CrossRef]

59. Singh, B.K.; Walker, A.; Morgan, A.J.W.; Wright, D.J. Effects of soil pH on the biodegradation of chlorpyrifos and isolation of a chlorpyrifos-degrading bacterium. Appl. Environ. Microbiol. 2003, 69, 5198-5206. [CrossRef] [PubMed]

60. Abd El-Azeem, S.A.; Ahmad, M.; Usman, A.R.; Kim, K.R.; Oh, S.E.; Lee, S.S.; Ok, Y.S. Changes of biochemical properties and heavy metal bioavailability in soil treated with natural liming materials. Environ. Earth Sci. 2013, 70, 3411-3420. [CrossRef]

61. Menon, P.; Gopal, M.; Prasad, R. Influence of two insecticides, chlorpyrifos and quinalphos, on arginine ammonification and mineralizable nitrogen in two tropical soil types. J. Agric. Food Chem. 2004, 52, 7370-7376. [CrossRef]

62. Shan, M.; Fang, H.; Wang, X.; Feng, B.; Chu, Q.; Yu, Y.L. Effect of chlorpyrifos on soil microbial populations and enzyme activities. J. Environ. Sci. China 2006, 18, 4-5.

63. Tejada, M.; Gomez, I.; del Tor, M. Use of organic amendments as a bioremediation strategy to reduce the bioavailability of chlorpyrifos insecticide in soils. Effects on soil biology. Ecotoxicol. Environ. Saf. 2011, 74, 2075-2081. [CrossRef]

64. Tejada, M.; Hernandez, M.T.; Garcia, C. Soil restoration using composted plant residues: Effects on soil properties. Soil Tillage Res. 2009, 102, 109-117. [CrossRef] 